\title{
SPRAWOZDANIE Z IX WARSZAWSKO-TORUŃSKIEGO KOLOKWIUM NAUKOWEGO PRAW CZŁOWIEKA I MIĘDZYNARODOWEGO PRAWA HUMANITARNEGO „PRAWA CZEOWIEKA A OCHRONA ŚRODOWISKA - WSPÓLNE WARTOŚCI I WYZWANIA", TORUŃ, 9-10 GRUDNIA 2016 ROKU
}

\section{REPORT ON THE IX WARSAW-TORUŃ COLLOQUIUM ON HUMAN RIGHTS AND INTERNATIONAL HUMANITARIAN LAW "HUMAN RIGHTS AND ENVIRONMENTAL PROTECTION - COMMON VALUES AND CHALLENGES", TORUŃ, 9-10 DECEMBER, 2016}

\section{STRESZCZENIE}

W dniach 9-10 grudnia 2016 roku odbyło się w Toruniu IX Warszawsko-Toruńskie Kolokwium Naukowe Praw Człowieka i Międzynarodowego Prawa Humanitarnego organizowane przez Katedrę Praw Człowieka Wydziału Prawa i Administracji UMK we współpracy z Ka- 
tedrą Prawa Ochrony Środowiska WPiA UMK i Kujawsko-Pomorskim Akademickim Centrum Prawa Ochrony Środowiska przy WPiA UMK. Tegoroczny temat przewodni tego cyklicznego wydarzenia łączył dwa główne obszary badawcze - praw człowieka i prawa ochrony środowiska.

\section{Słowa kluczowe}

Prawa człowieka; prawo ochrony środowiska; konferencja naukowa.

\section{ABSTRACT}

IX Warsaw-Toruń Colloquium on Human Rights and International Humanitarian Law took place in Torun between 9-10 December 2016. It was organised by the Department of Human Rights and the Department of Environmental Law of Faculty of Law and Administration of Nicolaus Copernicus University and the Kuyavian-Pomeranian Academic Centre of Environmental Law. This year's topic of the Colloquium brought together two general areas of scientific research - human rights and environmental law.

\section{Keywords}

Human rights; environmental law; scientific conference.

Warszawsko-Toruńskie Kolokwium Naukowe Praw Człowieka i Międzynarodowego Prawa Humanitarnego jest cykliczną inicjatywą naukową organizowaną naprzemiennie przez Katedrę Praw Człowieka Wydziału Prawa i Administracji Uniwersytetu Mikołaja Kopernika w Toruniu oraz Katedrę Ochrony Praw Człowieka Wydziału Prawa i Administracji Uniwersytetu Kardynała Stefana Wyszyńskiego w Warszawie. IX już Kolokwium odbyło się w dniach 9-10 grudnia 2016 roku w Toruniu. Z uwagi na wybrany temat przewodni, koncentrujący się wokół zagadnienia związków między prawami człowieka i prawnymi aspektami ochrony środowiska, główni organizatorzy zaprosili 4/2016 do współpracy Katedrę Prawa Ochrony Środowiska WPiA UMK 
i, powiązane z nią, Kujawsko-Pomorskie Akademickie Centrum Prawa Ochrony Środowiska (KPACPOŚ). Członkami Komitetu Organizacyjnego IX Kolokwium byli: prof. dr hab. Bożena Gronowska (Kierownik KPCz WPiA UMK), prof. dr hab. Bartosz Rakoczy (Kierownik KPOŚ WPiA UMK i KPACPOŚ), dr hab. Michał Balcerzak, prof. UMK oraz dr Julia Kapelańska-Pręgowska. Patronat honorowy nad IX Kolokwium objęła pani Emilia Kawka-Patek - Prezes Zarządu Wojewódzkiego Funduszu Ochrony Środowiska i Gospodarki Wodnej w Toruniu.

Dwudniowe obrady IX Kolokwium odbywały się w dwóch turach sesji - trzech plenarnych (piątek 9 grudnia 2016 roku) i czterech panelowych (sobota 10 grudnia 2016 roku). Uczestnicy czynni IX Kolokwium (łącznie 34 referentów) w swoich wystąpieniach analizowali zagadnienia łączące się przede wszystkim z następującymi obszarami badawczymi: prawa człowieka, prawo międzynarodowe i prawo ochrony środowiska. W części pierwszej referentów i pozostałych uczestników przywitali Kierownicy Katedr współpracujących przy IX Kolokwium - prof. dr hab. Bożena Gronowska i prof. dr hab. Bartosz Rakoczy, a następnie przemówienie powitalne do uczestników wygłosił pan Wojciech Kuliński, Zastępca Prezesa WFOŚiGW w Toruniu.

I sesja plenarna IX Kolokwium, prowadzona przez prof. dr hab. Bożenę Gronowską, poświęcona była tematyce: Prawo człowieka do czystego, zdrowego i zrównoważonego środowiska - perspektywa globalna. W jej ramach przedstawionych zostało pięć wystąpień:

- prof. dr hab. Janina Ciechanowicz-McLean (UG), Prawa człowieka do życia i do środowiska;

- dr hab. Jacek Barcik (UŚ), Środowisko jako globalne dobro publiczne;

- dr hab. Zbigniew Bukowski, prof. UKW (UKW w Bydgoszczy), Koncepcja zrównoważonego rozwoju a prawa człowieka;

- dr Łukasz Kułaga (UKSW), Zrównoważony rozwój a prawa człowieka w świetle Agendy 2030;

- dr Diana Trzcińska (UG), Sprawiedliwość ekologiczna $w$ systemie prawa ochrony środowiska. Wartość czy wyzwanie dla praw człowieka. 
W ramach II sesji plenarnej Prawo człowieka do czystego, zdrowego i zrównoważonego środowiska $w$ orzecznictwie EKPS, ETPC i Sądu Najwyższego USA, odbywającej się pod przewodnictwem dr hab. Balcerzaka, prof. UMK, wystąpienia mieli następujący referenci:

- prof. dr hab. Tadeusz Jasudowicz (UMK), Prawa człowieka a ochrona środowiska $w$ ujęciu Europejskiego Komitetu Praw Socjalnych;

- dr Hanna Morawska (UKSW), Prawo do środowiska jako prawo gwarantowane przez Europejska Konwencję Praw Człowieka. Uwagi de lege lata i de lege ferenda;

- dr Jakub Czepek (UWM), Gwarancje ochrony przed zagrożeniami ekologicznymi wynikające z Europejskiej Konwencji Praw Człowieka na gruncie prawa do życia;

- mec. Michał Behnke, Zanieczyszczenie środowiska jako naruszenie prawa do prywatności - refleksje na tle orzecznictwa Europejskiego Trybunału Praw Człowieka;

- dr hab. Jacek Skrzydło (UŁ), Ochrona środowiska naturalnego w orzeczeniach Sądu Najwyższego USA.

W trakcie ostatniej sesji plenarnej, odbywającej się pod hasłem Prawa człowieka a ochrona środowiska - perspektywa krajowa i pod przewodnictwem prof. dr hab. Janiny Ciechanowicz-McLean (UG) referaty wygłosili przedstawiciele nauki prawa ochrony środowiska:

- dr hab. Adam Habuda (INP PAN), Prawo jednostki do środowiska $w$ ustawodawstwie, orzecznictwie i doktrynie;

- prof. dr hab. Bartosz Rakoczy (UMK), Prawo do korzystania z wody a ochrona środowiska;

- dr Małgorzata Szalewska (UMK), Ochrona przed hałasem a ochrona praw człowieka;

- dr Maciej Nyka (UG), Partycypacyjne prawa w ochronie środowiska jako element ochrony środowiska morskiego Morza Bałtyckiego;

- dr Joanna Kierzkowska (GSW), Prawo do powietrza wolnego od zanieczyszczeń z „niskiej emisji”.

Drugi dzień obrad IX Kolokwium obejmował cztery sesje panelowe: 
- sesja IV: Prawa człowieka a ochrona środowiska - problemy prawnomiędzynarodowe, pod przewodnictwem prof. dr hab. Elżbiety Karskiej (UKSW);

- sesja V: Prawa człowieka a ochrona środowiska - problemy aksjologiczne i kulturowe, której przewodniczył dr hab. Sebastian Sykuna, prof. UG (UG);

- sesja VI: Współczesne problemy praw człowieka $w$ kontekście ochrony praw człowieka $w$ Polsce, pod przewodnictwem prof. dr hab. Bartosza Rakoczego;

- sesja VII: Wspótczesne problemy praw człowieka $w$ kontekście ochrony praw człowieka $w$ Europie i na świecie, której przewodniczył prof. dr hab. Tadeusz Jasudowicz (UMK).

W sesji IV swoje wystąpienia przedstawili:

- dr Marcin Kałduński (UMK), Zasada przezorności w międzynarodowym prawie środowiska;

- dr Samanta Kowalska (UAM), Ekoterroryzm - rozważania $w$ kontekście bezpieczeństwa $i$ zasady zrównoważonego rozwoju. Wybrane regulacje prawa międzynarodowego;

- dr Julia Kapelańska-Pręgowska i dr Piotr Sadowski (UMK), Środowisko naturalne $w$ sytuacji konfliktu zbrojnego - perspektywa prawnomiędzynarodowa;

- dr Agnieszka Wedeł-Domaradzka (UKW), Prawo dziecka do bezpiecznego, czystego i zrównoważonego środowiskanowe wyzwania $w$ perspektywie postanowień Konwencji o Prawach Diiecka;

- mgr Patrycja Zgoła (INP PAN), Deterytorializacja klimatyczna państwa a status prawny uchodźcy $w$ dokumentach prawa międzynarodowego.

$\mathrm{W}$ trakcie równolegle odbywającej się sesji V referaty wygłosili następujący uczestnicy:

- dr Dorota Ferenc-Kopeć (Rzeszowska Szkoła Wyższa), Środowisko naturalne i prawa człowieka - problem wzajemnych konwergencji. Ujęcie kulturowe;

- dr Tomasz Bojar-Fijałkowski (UKW), Prawo do czystego, zdrowego i zrównoważonego środowiska $w$ założeniach sprawiedliwości ekologicznej; 
- dr Rafał Mizerski (UWM), Wspótczesna koncepcja praw człowieka $w$ świetle ustaleń paleoantropologii i antropogenetyki;

- mgr Katarzyna Wesołowska (SKO w Koninie), Prawo człowieka do przyrody;

- mgr Adrian Pachciarz (UMK), Środowisko i prawa człowieka $w$ nauczaniu Jana Pawła II.

W ramach przedostatniej sesji panelowej IX Kolokwium swoje wystąpienia przedstawiły:

- dr Katarzyna Grzelak-Bach (UKSW), Kilka uwag na tle prawa łowieckiego;

- dr Karolina Karpus (UMK), Implementacja dyrektywy 2007/2/WE Parlamentu Europejskiego i Rady z dnia 14 marca 2007 ustanawiajacej infrastrukture informacji przestrzennej we Wspólnocie Europejskiej a prawo do informacji o środowisku i jego ochronie;

- mgr Klaudia Cholewa (UŚ), Manifestacja prawa do środowiska $w$ wybranych regulacjach odpadowych;

- mgr Martyna Walas (UMK), Prawo do korzystania z lasów i jego ograniczenia $w$ prawie polskim.

W sesji VII wystąpienia miały następujące prelegentki:

- dr Dagmara Jaroszewska-Choraś (UG), „Nowe” prawa człowieka. Dostęp do wody pitnej i infrastruktury sanitarnej;

- dr Joanna Rezmer (UMK), Prawo do informacji dotyczacej niebezpiecznych substancji i odpadów;

- mgr Filip Nawrot (UŚ), Prawo do czystego środowiska a implementacja dyrektywy 2008/98/WE w Polsce i we Wtoszech;

- mgr Katarzyna Zawada (UŚ), Wptyw doświadczenia katastrofy $w$ Czarnobylu na regulacje dotyczace awarii technicznych $w$ ustawodawstwie rosyjskim.

Po zakończeniu sesji panelowych podsumowanie dwóch dni obrad w ramach IX Kolokwium przedstawiła prof. dr hab. Bożena Gronowska, zwracając uwagę na liczne i rosnące związki między obszarami badawczymi, odzwierciedlone i analizowane $\mathrm{w}$ trakcie wystąpień prelegentów, przedstawiających z różnych 4/2016 perspektyw problematykę przenikania się praw człowieka, mię- 
dzynarodowego prawa humanitarnego i prawa ochrony środowiska.

Wyniki tychże analiz znajdą swoje posumowanie $\mathrm{w}$ planowanej monografii naukowej, poświęconej tematyce przewodniej IX Kolokwium, pt. Prawa człowieka a ochrona środowiska wspólne wartości i wyzwania.

(oprac. Redakcja PPOŚ) 